\title{
Science as the arbitrator of 'truth' in (German) feminist linguistic debates ${ }^{1}$
}

\author{
Christiane Luck \\ University College London
}

\section{Abstract}

The feminist critique of language has been contested from its very inception. Opponents have distanced themselves from feminist proposals by arguing, for example, that language and reality are separate entities; that linguistic disparity is insignificant in comparison to other forms of discrimination; and most of all, that feminist approaches are 'unscientific'. In this paper, I explore the late 1970s dispute between Senta Trömel-Plötz, Hartwig Kalverkämper and Luise F. Pusch as a particular example of the feminist vs. 'scientific' position. These three linguists are prominent voices in the German-language context and their arguments provide a valuable insight into the nature of gender and language debates in general. As I aim to show in the following, even empirical evidence does not necessarily bring a close to the discussions.

Keywords: feminist linguistics, German, gender, Trömel-Plötz, Pusch

\section{A brief history}

To set the scene for the dispute between Senta Trömel-Plötz, Hartwig Kalverkämper and Luise F. Pusch, a brief historical overview of feminist linguistic debates is needed. While it is of course difficult, if not impossible, to pinpoint the exact moment when gender came to the forefront of linguists' minds, Robin Lakoff's 1973 essay 'Language and Woman's Place' is often considered a key starting point. As Lenora A. Timm comments in her review of Lakoff's essay, '[Lakoff] has done pioneering work in an area which hitherto had been fairly well neglected by linguists, and even by sociolinguists' (1976: 251). Inspired by the civil rights movement in the United States during the 1960s, Lakoff was one of the first linguists to put the focus on women's disparate treatment in language. Two of her observations regarding gender and language 
are here of particular interest. On the one hand, Lakoff considers societal power and linguistic practices as essentially linked, and on the other, she sees the different power positions reflected in language.

In reference to her first observation Lakoff states: ' $t$ ] he language of the favored group, the group that holds the power, along with its non-linguistic behavior, is generally adopted by the other group, not vice-versa' (1973: 50). In short, those who hold societal power seem to dictate general language use as well. Regarding her second observation she comments, '[o]ften a word that may be used of both men and women ..., when applied to women, assumes a special meaning that, by implication rather than outright assertion, is derogatory to women as a group' (1973: 57). In addition to the dominance of the 'favored group' in terms of use, the 'other group' is also limited in meaning. The term 'professional' is one example given by Lakoff, which often has very different connotations when used for women and men. Male professionals are, according to the author, generally perceived as experts in a certain professional field who happen to have a sex. Professionals who are women, however, are often considered 'professional' in the latter sense only. According to Lakoff, with men as the 'favoured group', and further, with women predominantly restricted to sexual beings in relation to men, a professional 'minus male' can only be a prostitute.

Senta Trömel-Plötz, who obtained her PhD in the U.S., was strongly influenced by work such as Lakoff's. When Trömel-Plötz returned to Germany, she transferred the feminist critique of the English language to her native context. Her 1978 essay 'Linguistik und Frauensprache' (Linguistics and Women's Language ${ }^{2}$ problematised women's representation in the German language for the first time.

\section{Senta Trömel-Plötz}

In agreement with Lakoff, Trömel-Plötz considers the linguistic treatment of women a central expression of bias. She states, '[d]ie Diskriminierung besteht gerade sehr oft darin, wie eine Frau angeredet oder nicht angeredet wird' (discrimination manifests itself very often in the way women are addressed or not addressed) (1978: 50). Just as in the English language, Trömel-Plötz proposes, terms such as 'professional' largely connote 'male' in German. The connotation 'female' often becomes visible only in the specific. But while the English language has the impact of social gender to contend with, German is additionally burdened with grammatical gender. 'Der Profi', 'der Fachmann' or 'der Experte', which are all translations of the term 'professional', are grammatically masculine as well.

Trömel-Plötz uses the example 'der Zuhörer, er' (the listener, he), to illustrate the issue. 'Der Zuhörer, er' is meant to address both men, and women and men collectively. However, if only women are addressed, 'der Zuhörer, er' is always modified to 'die Zuhörerin, sie' (the listener, she) (1978: 51-52). Unsurprisingly, this causes confusion as to when and whether women are addressed by 'der Zuhörer, er'. Trömel-Plötz believes the default understanding of terms such as 'der Zuhörer, er' is 'male' first and foremost. These terms are 
therefore often described as generic masculine terms and the weighting towards

LUCK the connotation 'male' has the following effect according to Trömel-Plötz: 'das maskuline grammatische Geschlecht und der Mann als Referent [sind] die Norm ... und die femininen Formen mit der Frau als Referent die Abweichung. Der Mann dominiert auch in der Sprache' (the masculine grammatical gender and man as the referent are the norm ... and the feminine forms with woman as the referent the deviation. Man also dominates in language) (1978: 56). In line with Lakoff, the author considers societal power and linguistic practices to be linked.

Trömel-Plötz's essay was published in Linguistische Berichte, which is a prominent and widely-read journal. Among its readership are proponents of her ideas, but also opponents to her point of view. Hartwig Kalverkämper is a central voice of the counter-argument and I discuss his 1979 response to Trömel-Plötz's 'Die Frauen und die Sprache' (Women and Language) next.

\section{Hartwig Kalverkämper}

In the following analysis of Hartwig Kalverkämper's argument, I am particularly interested in the language he employs to deconstruct Trömel-Plötz's position. Kalverkämper considers himself to occupy a, if not the, scientific position. And in doing so, he tries to distance himself from Trömel-Plötz's line of reasoning. As he states in the introduction to his essay: '[d]abei geht es mir nicht darum ... mich an dem plakativen Geschlechterstreit und Rollenkampf direkt zu beteiligen ...; es geht mir vielmehr darum, die linguistische Wissenschaftsposition, die methodologischen Implikationen des Beitrags unter die Lupe zu nehmen' (I am not interested in participating in the blatant battle of the sexes; I am concerned with analysing the linguistic and scientific position, and the methodological implications of [Trömel-Plötz's] contribution) (1979: 56). And as the reader learns throughout the course of Kalverkämper's essay, linguistics as a science is everything Trömel-Plötz's argument is not.

To give a few examples from his analysis; Kalverkämper states that semantics is 'logisch inspiriert' (inspired by logic) (1979: 58) while TrömelPlötz's methodology shows 'Verlorenheit der Gedankengänge' (incoherent trains of thought) (1979: 60). Kalverkämper argues, '[er geht] die Problemlage, ein sprachliches Phänomen, linguistisch an' (he approaches the issue, a linguistic phenomenon, linguistically) (1979: 65) while Trömel-Plötz's approach is 'unlinguistisch' (un-linguistic) (1979: 60). And finally, Kalverkämper says one should show 'Verantwortung vor der Wissenschaft' (responsibility toward science) (1979: 60) whereas Trömel-Plötz's work is 'unwissenschaftlich' (unscientific) (1979: 67). In short, the author believes he has objective distance from the issue while Trömel-Plötz does not. Kalverkämper bases this judgement on Trömel-Plötz's linking of grammatical gender and biological sex. Generic masculine terms, according to the author, do not evoke men rather than women but are simply an efficient feature of language.

Nevertheless Kalverkämper does admit: '[d]as soll allerdings nicht kategorisch besagen, daß die Sprachgemeinschaften in Einzelfällen nicht doch eine Beziehung zwischen Genus und Sexus, zwischen Sexus und Genus 
erstellten' (this does not mean that speech communities have not created a link between grammatical gender and sex, between sex and grammatical gender in certain individual cases) (1979: 60). Such cases might be 'die Mutter, sie' (the mother, she), which is always grammatically feminine, or 'der Vater, er' (the father, he) which is always masculine. While these are obvious and seemingly isolated examples, Kalverkämper further reveals that these 'certain individual cases' are not quite as 'individual' as he first makes them out to be. In fact, the link between grammar and sex is well established as the author explains in his comment on job titles: '[e]rst in einer Zeit, in der Frauen in öffentliche Stellen, in die verschiedensten Berufssparten drängen, wird man sich der Notwendigkeit bewußt, für die neuen Inhaberinnen dieser Stellen neue Berufsbezeichnungen zu suchen' (only once women enter the public sector, and other diverse lines of business, will speakers realise the necessity to find new job titles for the holders of these roles) (1979: 61). In effect, Kalverkämper confirms that terms such as 'der Minister' (the minister), 'der Bundeskanzler' (the chancellor) and 'der Experte' (the professional) connote 'male' despite their supposed gender-neutrality. Only the creation of terms such as 'die Ministerin', 'die Bundeskanzlerin' und 'die Expertin', according to the author, will express otherwise.

Considering that Kalverkämper in essence agrees with Trömel-Plötz, what exactly makes her position unscientific? Luise F. Pusch's 1979 essay 'Der Mensch ist ein Gewohnheitstier, doch weiter kommt man ohne ihr' (The human is a creature of habit but you get further without her) picks up on the confusion of Kalverkämper's argument.

\section{Luise F. Pusch}

Luise F. Pusch is a prominent voice in the German-language context and her 1979 response to Kalverkämper established her as a key proponent of the feminist critique of language. In contrast to Kalverkämper, Pusch argues in close proximity to Trömel-Plötz's position. Her answer to the author's claim that Trömel-Plötz presents an incoherent argument on grammar and sex is as follows. 'Trömel-Plötz "verwechselt" nicht Sexus und Genus, sondern sie analysiert gezielt die Beziehungen zwischen der grammatischen Kategorie Genus und dem Sexus der Referent/inn/en' (Trömel-Plötz does not "confuse" sex and grammatical gender but analyses the relationship between the grammatical category and the sex of the referent) (1979: 96). In fact, Pusch believes Kalverkämper misunderstood Trömel-Plötz's position to begin with. She adds: '[e]s geht ... eindeutig um ein referenzsemantisches Problem, um die Frage nämlich, ob Aussagen mit Personenbezeichnungen aller Art ..., tatsächlich in der postulierten Weise funktionieren' (this is clearly a reference-semantic issue; the question is whether terms really refer to human beings as they claim to) (1979: 94).

That 'claim' and reality are often at odds is effectively illustrated by Kalverkämper himself. However, even in his subsequent response to Pusch, 'Quo Vadis Linguistica? - Oder: Der feministische Mumpsimus* in der Linguistik' (Feminist Mumpsimus in Linguistics), he refuses to amend his original position. To Kalverkämper, feminist linguistics remains 'unscientific'. 
In the late 1970s, the theoretical argument seems at a dead-end. Inspired by, or more accurately, frustrated with, this ideological deadlock, empirical researchers have tried to open up the debate.

\section{Empirical studies}

Josef Klein’s 1988 ‘Benachteiligung der Frau im generischen Maskulinum - eine feministische Schimäre oder psycholinguistische Realität?' (Discrimination of women by generic masculine terms? - a feminist delusion or psycholinguistic reality?) is one study attempting to determine which position holds most merit. To find out, Klein conducted two tests: 'Test A' included 158 participants, among them 84 women, and 'Test B' 74 female and 54 male respondents. He explains, 'für Test A [wurden] kurze Texte entworfen, deren Kopf-Satz jeweils ein generisches Maskulinum enthält, z.B. "Jeder Einwohner der Stadt Aachen ..." (for Test A short texts were created of which the first sentence included a generic masculine term, such as "Every citizen (masculine) of Aachen ...") (1988: 312). Participants were then asked to select the most suitable referent.

To distract respondents from the true nature of the experiment, the focus was placed on stylistic rather than sex-specific choices. Participants were required to select amongst 'first name-last name' or 'title-last name' options, such as 'Nicola Meier' or 'Frau Meier'. Visualised in a graph, Klein's findings look like this (see Figure 1 below):

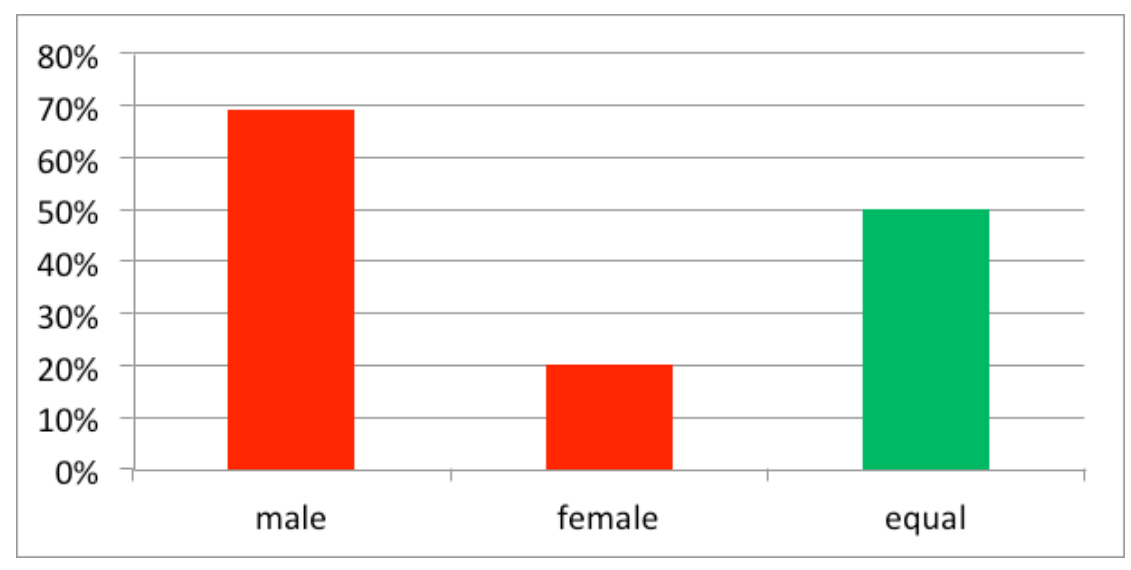

Figure 1: Participants' interpretation of 'citizen (masc.)' in contrast to an equal understanding

The author explains, '[v] on der Gesamtgruppe werden $69 \%$ der Lücken durch Nennung eines männlichen Vornamens oder der Anredeform "Herr" und nur $20 \%$ durch Nennung einer entsprechenden weiblichen Form ausgefüllt' (the participants chose a male first name or the title 'Mr' $69 \%$ of the time, and the female equivalent only $20 \%$ of the time) (1988: 315). In short, respondents seem to interpret the generic masculine term as predominantly 'male'. 
'Test B' acted as a point of comparison. Generic masculine terms were replaced with dual-forms, such as 'Jede Einwohnerin/jeder Einwohner der Stadt Aachen' to allow for women's linguistic visibility. However, as Klein comments:

[O]bwohl die grammatische Struktur der feminin/maskulinen Doppelform die Testpersonen geradezu aufdringlich darauf stößt, daß der jeweiligen Personengruppe Frauen in gleichem Maße wie Männer angehören, bleibt auch hier das Übergewicht männlicher Geschlechtsspezifizierung und damit eine deutliche Prädominanz der Assoziation "Mann" ....

(Even though the participants are reminded explicitly by the grammatical structure of the feminine/masculine dual-form that women are equally part of the group as men, the sex-specification "male" and the association "man" remain distinctly predominant.) (1988: 316)

Consequently, the bias male-as-norm impacts on participants' ability to imagine female 'inhabitants' whether the masculine grammatical gender is used generically or not. But as Klein concludes, '[d] as generische Maskulinum hat allerdings eine deutliche Verstärkerwirkung. Bei seiner Verwendung liegt der Vorsprung männlicher Geschlechtsspezifizierung ... im Durchschnitt um $18 \%$ höher' (generic masculine terms increase the sex-specification "male", which is on average 18\% higher) (1988: 319). This effectively confirms Trömel-Plötz's position.

One study is, of course, not enough to conclude an argument, and various empirical studies have been undertaken since. Lisa Irmen and Astrid Köhncke's 1996 research 'Zur Psychologie des "generischen” Maskulinums' (On the psychology of "generic" masculine terms) presented 45 participants, among them 27 women, with sentences in which a key term was underlined. Respondents had to decide whether the previously highlighted term, such as a relatively gender-neutral job title, corresponded with a certain category presented in the follow-up sentence. Irmen and Köhncke found: '[d]er Itemtyp GM-F [generisches Maskulinum und Frau als Kategorie] wurde in der Regel mit "nein" beantwortet' (the correspondence of a generic masculine term with women as category was generally answered by "no") (1996: 159).

Karin M. Frank-Cyrus and Margot Dietrich's 1997 study 'Sprachliche Gleichbehandlung von Frauen und Männern in Gesetzestexten: Eine Meinungsumfrage der Gesellschaft für deutsche Sprache' (Linguistic equality of women and men in legal texts: A survey by the Gesellschaft für deutsche Sprache) followed on to compare the perception of generic masculine terms, such as 'der Vertreter, er' (the representative, he) to more gender-inclusive forms, such as 'Vertreter und Vertreterinnen'. 734 respondents, of them 63\% women, were asked to assess which version adequately represented women and men. In a graph participants' perceptions of generic masculine terms look like this (see Figure 2): 


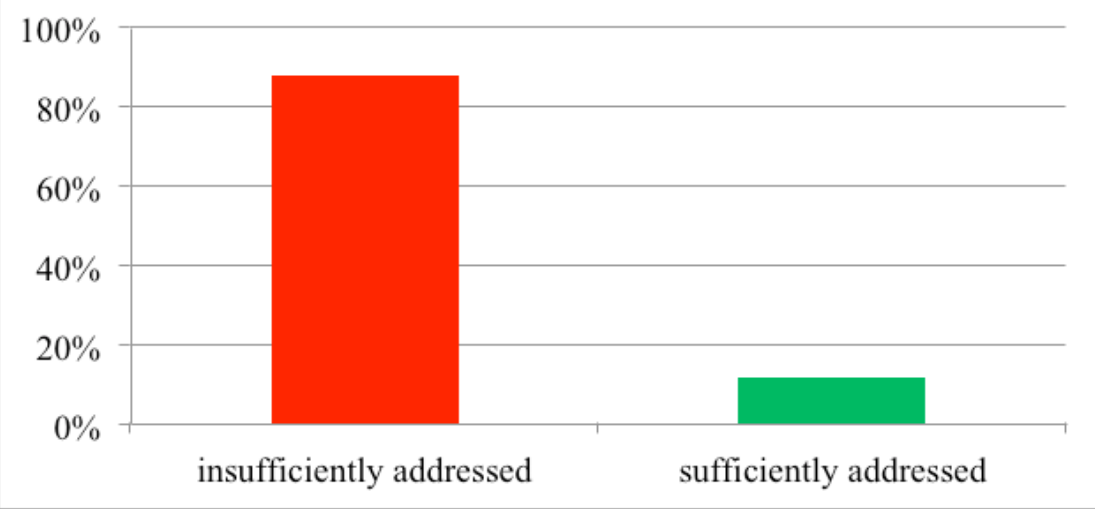

Figure 2: Participants' evaluation of generic masculine terms

Frank-Cyrus and Dietrich explain: ' 88 \% der Antwortenden finden Frauen beim Gebrauch generischer Maskulina ungenügend berücksichtigt ... $60 \%$ halten sie sogar für überhaupt nicht berücksichtigt' ( $88 \%$ of the respondents thought women were insufficiently addressed when generic masculine terms were used ... 60\% thought they were not addressed at all) (1997: 62).

None of the studies I consulted - the final being Dries Vervecken, Bettina Hannover and Ilka Wolter's 2013 German- und Dutch-language study 'Changing (S)expectations: How Gender Fair Job Descriptions Impact Children's Perceptions and Interest Regarding Traditionally Male Occupations' - showed any evidence for Kalverkämper's position. In effect, empirical science seems on the side of Trömel-Plötz and Pusch. But what impact did these empirical results have on the argument between Trömel-Plötz, Kalverkämper and Pusch? Did they bring closure to the debate on gender and language? In the final section of this paper I evaluate recent responses to women's and men's linguistic representation in an attempt to provide an answer.

\section{Contemporary responses}

As those who have been watching the 2014 FIFA World Cup might know, the German national anthem still sings of 'Vaterland' (fatherland) and 'brüderlich' (brotherly) rather than 'Heimatland' (homeland) and 'gemeinschaftlich' (jointly). Masculine language use is still fairly common-place in Germany, and it is not only common-place, changes continue to be strongly resisted. A recent amendment of the constitution of the Universität Leipzig shows how deep the resistance runs - and how similar the presented arguments sound to Kalverkämper's position.

In June 2013, the Universität Leipzig amended generic masculine terms, such as 'Professoren', in its constitution to generic feminine terms, such as 'Professorinnen'. Despite plausible counter-arguments of simply 'reversingthe-roles', this change makes sense on three accounts. Firstly, 'Professorinnen' can be argued to linguistically include 'Professoren' whereas the reverse cannot. 
Secondly, the use of one term, rather than the dual-form 'Professoren and Professorinnen', eases communication. And thirdly, 'Professorinnen' makes women more linguistically visible. Considering that this change only concerns the constitution and not any other language use, one might assume responses would be equally moderate. But, as the 62 comment pages to the Spiegel Online article 'Sprachreform an der Uni Leipzig: Guten Tag, Herr Professorin' (Language reform at the Universität Leipzig) show, Kalverkämper's arguments are still alive today.

According to many language users, feminist language change is still considered 'Blödsinn' (nonsense); 'albern und peinlich' (silly and embarrassing); and essentially 'unlinguistisch' (un-linguistic). One commentator effectively reproduces Kalverkämper’s position: '[d]er Gebrauch des generischen Maskulinum ist nicht Ausdruck einer patriarchalischen Weltordnung, sondern, total unpolitisch, Ausdruck von Spracheffizienz' (the use of generic masculine terms is not an expression of a patriarchal world-order, but entirely apolitically, an expression of linguistic efficiency) (2013: n. pag.). Equally, linguists carry on debates similar to those of the 1970s (see the exchange between Hans-Martin Gauger and Luise F. Pusch in particular).

While empirical studies might support Trömel-Plötz and Pusch's position, as the above examples illustrate, the feminist critique of language remains a contested field and the debate around gender and language ongoing. In effect, the dominant standpoint seems to hold sway in spite of the empirical evidence. This poses the question: is science really an arbitrator of truth in feminist linguistic debates? Nevertheless, the new constitution of the Universität Leipzig is a poignant example of what Trömel-Plötz and Pusch have achieved. Over the past forty years, despite continued opposition from both within and outside of academia, feminist linguists have raised considerable awareness of discrimination through (German) language use as well as affected change. Whatever the attempts to keep more inclusive language use at a distance, the work of feminist linguists continues to bring it closer to becoming a reality.

\section{Endnotes}

1 The argument and discussion in this paper form part of my thesis.

2 All translations are my own.

\section{Works Cited}

Frank-Cyrus, Karin M., and Margot Dietrich. 'Sprachliche Gleichbehandlung von Frauen und Männern in Gesetzestexten: Eine Meinungsumfrage der Gesellschaft für deutsche Sprache'. Der Sprachdienst 41.2 (1997): 55-68. Print. Gauger, Hans-Martin. 'Herr Professorin?' deutscheakademie.de. 2014. Web. 14 Sept. 2014.

Haerdle, Benjamin. 'Sprachreform an der Uni Leipzig: Guten Tag, Herr Professorin.' UniSPIEGEL 31 May 2013. Web. 26 Feb. 2014.

Irmen, Lisa, and Astrid Köhncke. 'Zur Psychologie des "Generischen" 
Maskulinums.' Sprache \& Kognition 15.3 (1996): 152-66. Print.

Kalverkämper, Hartwig. 'Die Frauen und die Sprache'. Linguistische Berichte 62 (1979): 55-71. Print.

---. 'Quo Vadis Linguistica? - Oder: Der Feministische Mumpsimus* in der Linguistik.' Linguistische Berichte 63 (1979): 103-07. Print.

Klein, Josef. 'Benachteiligung der Frau im generischen Maskulinum - Eine feministische Schimäre oder psycholinguistische Realität?' Das Selbstverständnis Der Germanistik: Aktuelle Diskussionen. Ed. Norbert Oellers. Tübingen: Max Niemeyer Verlag, 1988. 310-19. Print.

Lakoff, Robin. 'Language and Woman's Place.' Language in Society 2.1 (1973): 45-80. Print.

Pusch, Luise F. 'Der Mensch ist ein Gewohnheitstier, doch weiter kommt man ohne ihr - Eine Antwort auf KALVERKÄMPERs Kritik an TRÖMEL-PLÖTZ' Artikel über "Linguistik und Frauensprache." Linguistische Berichte 63 (1979): 84-102. Print.

Pusch, Luise F. 'Generisches Femininum erregt Maskulinguisten, Teil 1.' Laut \& Luise. fembio.org, 2013. Web. 14 Sept. 2014.

Timm, Lenora A. 'Robin Lakoff, Language and Woman's Place.' Lingua 39.3 (1976): 244-52. Print.

Trömel-Plötz, Senta. 'Linguistik und Frauensprache.' Linguistische Berichte 57 (1978): 49-68. Print.

\section{Biography}

Christiane Luck is a third-year PhD student at UCL at the Centre for Multidisciplinary \& Intercultural Inquiry (CMII). Her research project explores the potential of literature to further feminist linguistic thought. She is particularly interested in literary texts which problematise the concepts of gender-neutrality and gender-inclusivity. 